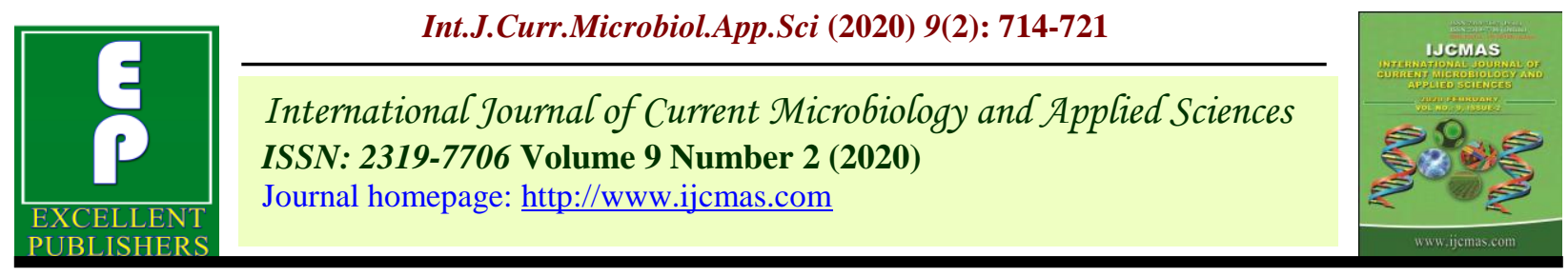

Original Research Article

https://doi.org/10.20546/ijcmas.2020.902.087

\title{
Compatibility of Entomopathogenic Fungi, Metarhizium anisopliae with Pesticides
}

\author{
D. S. Lavanya ${ }^{1^{*}}$ and Poornima Matti ${ }^{2}$ \\ ${ }^{1}$ Department of Agricultural Entomology, College of Agriculture, Dharwad-580005, India \\ ${ }^{2}$ Department of Agricultural Entomology, ARS Sankeshwar, Dharwad-580005, India \\ *Corresponding author
}

\begin{tabular}{|l|}
\hline K e y w o r d s \\
Compatibility, \\
$\begin{array}{l}\text { Metarhizium } \\
\text { anisopliae, } \\
\text { Pesticides etc. }\end{array}$ \\
\hline Article Info \\
\hline $\begin{array}{l}\text { Accepted: } \\
\text { 08 January } 2020 \\
\text { Available Online: } \\
\text { 10 February } 2020\end{array}$ \\
\hline
\end{tabular}

\section{A B S T R A C T}

The present investigation was conducted to test the compatibility of pesticides on entomopathogenic fungi, Metarhizium anisopliae. The in vitro toxicity of five insecticides(Fipronil5\% SC, Chlorpyriphos $20 \%$ EC, Imidacloprid + Fipronil80 \% WG, Imidacloprid $17.8 \%$ SL, Chlorantraniliprole $0.4 \% \mathrm{G}$ ), two fungicides (Hexaconazole $5 \% \mathrm{SC}$ and Propiconazole $25 \%$ EC) at different concentration for their effect on colony diameter, growth inhibition (\%) and spore yield of $M$. anisopliae by standard poison food technique. Compatibility of $M$. anisopliae revealed that among the various insecticides tested with $M$. anisopliae Fipronil5\% SCandChlorantraniliprole $0.4 \% \mathrm{G}$ showed highly compatible with least per cent growth inhibition with highest spore yield. Chlorpyriphos $20 \%$ EC, Hexaconazole 5\% SC and Propiconazole $25 \%$ ECshowed cent per cent inhibition and were most detrimental to the entomopathogen.

\section{Introduction}

Entomopathogenic fungi are important natural biological control agents of many insects, including several pests (Carruthers and Hural, 1990). In Integrated Pest Management (IPM) programs accomplishment of entomopathogens, is one of a technique that should be considered as an important pest reduction factor. The use of incompatible insecticides may affect the growth, development and germination of these pathogens, affecting IPM (Anderson and Roberts, 1983). One of the adverse effects of insecticides is killing the non-target organisms which also feed on the pests, such as entomopathogenic fungi. However, it is very likely that interaction might have occurred between pesticides and entomopathogenic fungi (Akbar et al., 2012). 
On the other hand, the utilization of selective pesticides in association with pathogens can increase the efficiency of control, allowing the reduction of the amount of applied pesticides, minimizing environmental contamination hazards and the expression of pest resistance. The objective of this study was to evaluate the in vitro fungi toxic effect (selectivity /compatibility) of some newer insecticides and pesticides in relation to the entomopathogenic fungus $M$. anisopliae, an important natural control agent. Thus, the present study will be useful to generate some information regarding compatibility of fungal bio-pesticide with some newer pesticides and increasing the effectiveness of bio-pesticides for managing the pest.

\section{Materials and Methods}

An experiment was carried out in the post graduate laboratory of Department of Plant Pathology, College of Agriculture, University of Agricultural Sciences, Dharwad. The statistical design used was factorial completely randomised design with control (FCRD) with seven treatments and three replications. Three different concentrations of insecticides and fungicides (Table.1) commonly used in the field for the control of white grubs and diseases were used at their recommended field doses to check their compatibility with the entomopathogenic fungi

Five insecticides and two fungicides were evaluated by standard poison food technique (Moorhouse et al., 1992) in Potato Dextrose Agar (PDA) medium for the colony growth and germination of $M$. anisopliae. Requisite quantity of insecticides was incorporated into the melted sterile PDA media $(60 \mathrm{ml})$ in flask before solidification to get desired concentration aseptically, thoroughly mixed, poured into the 3 Petri plates of $9 \mathrm{~cm}$ diameter sterile petri dishes and allowed to solidify under laminar flow cabinet. Small disk $(5 \mathrm{~mm}$ dia.) cut from a 15 days old actively growing mycelium mat of $M$. anisopliae fungal be cut with sterile cork borer and placed aseptically into the centre of Petri plate containing the poison medium.

Growth medium (PDA) without insecticide but inoculated with mycelia disc served as untreated check. Each treatments were replicated thrice and incubated under room condition. The plates was sealed with Para film and incubated at at $27 \pm 2{ }^{\circ} \mathrm{C}$ temperature.

\section{Colony diameter and per cent inhibition}

Colony diameter of the fungus was measured at 7 and 10 days after inoculation and compared either standard check to measure the degree of toxicity (Nene and Thapliyal, 1997) of different pesticides used in the study. The per cent inhibition in radial growth over control was calculated by using the formula of Vincent (1947).

$\mathrm{I}=\frac{\mathrm{C}-\mathrm{T}}{\mathrm{C}} \times 100$

Where;

$\mathrm{I}=$ Per cent inhibition

$\mathrm{C}=$ Radial growth in control

$\mathrm{T}=$ Radial growth in treatment (pesticide).

After measuring the colony diameter on 10th day, $5 \mathrm{ml}$ of $75 \%$ ethanol was applied to each plate to kill the fungus and wet the conidia. The plate was then washed 10 times with 9.5 $\mathrm{ml}$ of $0.02 \%$ Tween 80 and aliquot was collected in separate vials. Number of conidia in each vial was determined using standard counting methods and the average number of conidia per colony in each plate was counted to measure the rate of sporulation ( $\mathrm{Li}$ and Holdom, 1994). 


\section{Results and Discussion}

Results of the studies indicated that at $7^{\text {th }}$ days after inoculation (DAI) among the different pesticides tested against $M$. anisopliae, fipronil $5 \% \mathrm{SC}$ at $1 / 2 \mathrm{RD}, \mathrm{RD}$ and $2 \mathrm{RD}$ resulted the least per cent inhibition of $37.57,44.44$ and 50.26 which is statistically on par with chlorantraniliprole $0.4 \% \mathrm{G}$ with per cent inhibition of 38.62, 43.39 and 50.69, followed by imidacloprid $40 \%+$ fipronil $40 \%$ WG with per cent inhibition of 43.92, 51.32 and 53.44. Imidacloprid $17.8 \% \mathrm{SL}$ at $2 \mathrm{RD}$ recorded the highest per cent of inhibition 82.12 whereas at $1 / 2 \mathrm{RD}$ and $\mathrm{RD}$ recorded the per cent inhibition of 56.61 and 65.61. However all the three concentrations of chlorpyriphos $20 \%$ EC, hexaconazole 5\% SC and propiconazole 25\% EC recorded 100 per cent growth inhibition compared to control.(Table.2 and Fig.1 ).

On $10^{\text {th }}$ DAI fipronil $5 \%$ SC at $1 / 2 \mathrm{RD}, \mathrm{RD}$ and 2RD resulted the least per cent inhibition of $30.89,32.11$ and 39.84 which is statistically on par with chlorantraniliprole $0.4 \% \mathrm{G}$ with per cent inhibition of 32.60, 39.84 and 41.63, followed by imidacloprid $40 \%+$ fipronil $40 \%$ WG with per cent inhibition of $35.77,39.84$ and 45.12 . Imidacloprid $17.8 \% \mathrm{SL}$ at $2 \mathrm{RD}$ recorded the highest per cent of inhibition 81.30 whereas at $1 / 2 \mathrm{RD}$ and $\mathrm{RD}$ recorded the per cent inhibition of 44.72 and 67.48. Irrespective of pesticidal concentrations chlorpyriphos $20 \%$ EC, hexaconazole 5\% SC and propiconazole $25 \%$ EC recorded 100 per cent growth inhibition compared to control (Table.3 and Fig.1).

The spore yield of $M$. anisopliaewhen mixed with pesticides depends upon its inhibitory action on colony growth. Result varied from $0.94 \times 10^{8}$ to $1.41 \times 10^{8}$ conidia per plate. Among the different pesticides fipronil 5\% $\mathrm{SC}$ and chlorantraniliprole $0.4 \% \mathrm{G}$ recorded significantly higher spore yield of $1.41 \times 10^{8}$ and $1.23 \times 10^{8}$. while the lower spore yield was observed in imidacloprid $40 \%$ + fipronil $40 \%$ WG of $1.15 \times 10^{8}$ followed by imidacloprid $17.8 \%$ SL of $0.94 \times 10^{8}$, whereas chlorpyriphos $20 \%$ EC, hexaconazole 5\% SC and propiconazole $25 \%$ EC yielded no spores.

Table.1 The details of the pesticides evaluated for compatibility with Metarhiziumanisopliaeare here under

\begin{tabular}{|c|c|c|c|c|c|c|}
\hline \multirow[t]{2}{*}{ no } & \multirow[t]{2}{*}{ Active ingredient } & \multirow[t]{2}{*}{ Formulation } & \multirow{2}{*}{$\begin{array}{l}\text { Trade } \\
\text { name }\end{array}$} & \multicolumn{3}{|c|}{ Dose $/ 100 \mathrm{ml}$ media in $\mu \mathrm{L}$ or $\mathrm{g}$} \\
\hline & & & & $1 / 2 \mathrm{RD}^{*}$ & $\mathrm{RD}$ & $2 \mathrm{RD}$ \\
\hline 1 & Fipronil & $5 \% \mathrm{SC}$ & Regent & 100 & 200 & 400 \\
\hline 2 & Chlorpyriphos & $20 \% \mathrm{EC}$ & Hyban & 500 & 1000 & 2000 \\
\hline 3 & $\begin{array}{l}\text { Imidacloprid + } \\
\text { Fipronil }\end{array}$ & $80 \% \mathrm{WG}$ & Lesenta & 0.0375 & 0.075 & 0.1125 \\
\hline 4 & Imidacloprid & $17.8 \% \mathrm{SL}$ & Confidor & 50 & 100 & 150 \\
\hline 5 & Chlorantraniliprole & $0.4 \% \mathrm{G}$ & Ferterra & 3 & 6 & 12 \\
\hline 6 & Hexaconazole & $5 \% \mathrm{SC}$ & Contaf & 50 & 100 & 200 \\
\hline 7 & Propiconazole & $25 \% \mathrm{EC}$ & Tilt & 50 & 100 & 200 \\
\hline 8 & Control & - & - & - & - & - \\
\hline
\end{tabular}

$* \mathrm{RD}=$ Recommended dose. 
Table.2 Effect of pesticides on colony diameter and growth inhibition of Metarhizium anisopliae on $7^{\text {th }}$ days after inoculation

\begin{tabular}{|c|c|c|c|c|c|c|c|}
\hline \multirow{3}{*}{$\begin{array}{l}\text { Sl. } \\
\text { No. }\end{array}$} & \multirow{3}{*}{ Pesticides } & \multicolumn{3}{|c|}{ Colony diameter $(\mathrm{mm})$} & \multicolumn{3}{|c|}{ Growth inhibition (\%) } \\
\hline & & \multicolumn{3}{|c|}{$7^{\text {th }}$ DAI* } & \multicolumn{3}{|c|}{$7^{\text {th }}$ DAI } \\
\hline & & $1 / 2 \mathbf{R D} * *$ & RD & 2RD & $1 / 2 \mathbf{R D}$ & RD & 2RD \\
\hline 1 & Fipronil 5\% SC & 19.7 & 17.5 & 15.7 & $\begin{array}{c}37.57 \\
(37.75)^{\mathrm{a}}\end{array}$ & $\begin{array}{c}44.44 \\
(41.87)^{\mathrm{ab}}\end{array}$ & $\begin{array}{c}50.26 \\
(45.15)^{\mathrm{a}}\end{array}$ \\
\hline 2 & Chlorpyriphos $20 \%$ EC & 0.00 & 0.00 & 0.00 & $\begin{array}{l}100 \\
(90)^{d}\end{array}$ & $\begin{array}{l}100 \\
(90)^{d}\end{array}$ & $\begin{array}{l}100 \\
(90)^{\mathrm{c}}\end{array}$ \\
\hline 3 & $\begin{array}{l}\text { Imidacloprid } 40 \%+\text { Fipronil } \\
40 \% \text { WG }\end{array}$ & 17.7 & 15.3 & 14.7 & $\begin{array}{c}43.92 \\
(41.50)^{b}\end{array}$ & $\begin{array}{c}51.32 \\
(45.76)^{b}\end{array}$ & $\begin{array}{c}53.44 \\
(46.97)^{\mathrm{a}}\end{array}$ \\
\hline 4 & Imidacloprid $17.8 \% \mathrm{SL}$ & 13.7 & 10.8 & 5.6 & $\begin{array}{c}56.61 \\
(48.80)^{c}\end{array}$ & $\begin{array}{c}65.61 \\
(54.11)^{\mathrm{c}}\end{array}$ & $\begin{array}{c}82.12 \\
(65.00)^{b}\end{array}$ \\
\hline 5 & Chlorantraniliprole $0.4 \% \mathrm{G}$ & 19.3 & 17.8 & 15.5 & $\begin{array}{c}38.62 \\
(38.41)^{\mathrm{ab}}\end{array}$ & $\begin{array}{c}43.39 \\
(41.20)^{\mathrm{a}}\end{array}$ & $\begin{array}{c}50.69 \\
(45.39)^{\mathrm{a}}\end{array}$ \\
\hline 6 & Hexaconazole $5 \%$ SC & 0.00 & 0.00 & 0.00 & $\begin{array}{l}100 \\
(90)^{d}\end{array}$ & $\begin{array}{l}100 \\
(90)^{\mathrm{d}}\end{array}$ & $\begin{array}{l}100 \\
(90)^{\mathrm{c}}\end{array}$ \\
\hline 7 & Propiconazole $25 \%$ EC & 0.00 & 0.00 & 0.00 & $\begin{array}{l}100 \\
(90)^{d}\end{array}$ & $\begin{array}{l}100 \\
(90)^{\mathrm{d}}\end{array}$ & $\begin{array}{l}100 \\
(90)^{\mathrm{c}}\end{array}$ \\
\hline 8 & Control & 31.5 & 31.5 & 31.5 & - & - & - \\
\hline & Factors & \multicolumn{3}{|c|}{ S.Em \pm} & \multicolumn{3}{|c|}{ C.D. at $1 \%$} \\
\hline & Insecticides (I) & \multicolumn{3}{|c|}{0.42} & \multicolumn{3}{|c|}{1.62} \\
\hline & Concentration $(\mathrm{C})$ & \multicolumn{3}{|c|}{0.27} & \multicolumn{3}{|c|}{1.06} \\
\hline & $\mathbf{I} \times \mathbf{C}$ & \multicolumn{3}{|c|}{0.74} & \multicolumn{3}{|c|}{2.81} \\
\hline & CV $(\%)$ & \multicolumn{6}{|c|}{1.97} \\
\hline
\end{tabular}

$\mathrm{DAI}=$ Days after inoculation, $* * \mathrm{RD}=$ Recommended dose, Figures in parentheses are arc sine transformed values, means followed by the same alphabets in columns do not differ significantly $(\mathrm{p}=0.01)$ by DMRT 
Table.3 Effect of pesticides on colony diameter, growth inhibition and spore yield of Metarhizium anisopliae on $10^{\text {th }}$ days after inoculation

\begin{tabular}{|c|c|c|c|c|c|c|c|c|}
\hline \multirow{3}{*}{$\begin{array}{l}\text { Sl. } \\
\text { No. }\end{array}$} & \multirow[t]{3}{*}{ Pesticides } & \multirow{2}{*}{\multicolumn{3}{|c|}{$\begin{array}{c}\text { Colony diameter }(\mathrm{mm}) \\
10^{\text {th }} \text { DAI* }\end{array}$}} & \multirow{2}{*}{\multicolumn{3}{|c|}{$\begin{array}{c}\text { Growth inhibition (\%) } \\
10^{\text {th }} \text { DAI }\end{array}$}} & \multirow{3}{*}{$\begin{array}{c}\text { Spore } \\
\text { yield } \\
\left(\times 10^{8}\right)\end{array}$} \\
\hline & & & & & & & & \\
\hline & & $1 / 2 \mathbf{R D}$ & RD & 2RD & $1 / 2 \mathbf{R D}$ & RD & 2RD & \\
\hline 1 & Fipronil 5\% SC & 28.33 & 27.83 & 24.66 & $\begin{array}{c}30.89 \\
(33.75)^{\mathrm{a}}\end{array}$ & $\begin{array}{c}32.11 \\
(34.51)^{\mathrm{a}}\end{array}$ & $\begin{array}{c}39.84 \\
(39.13)^{\mathrm{a}}\end{array}$ & 1.41 \\
\hline 2 & Chlorpyriphos $20 \%$ EC & 0.00 & 0.00 & 0.00 & ${ }_{(90)^{d}}^{100}$ & $\begin{array}{l}100 \\
(90)^{d}\end{array}$ & $\begin{array}{l}100 \\
(90)^{d}\end{array}$ & 0.00 \\
\hline 3 & $\begin{array}{l}\text { Imidacloprid } 40 \%+\text { Fipronil } \\
40 \% \mathrm{WG}\end{array}$ & 26.33 & 24.66 & 22.50 & $\begin{array}{c}35.77 \\
(36.72)^{b}\end{array}$ & $\begin{array}{c}39.84 \\
(39.13)^{\mathrm{b}}\end{array}$ & $\begin{array}{c}45.12 \\
(42.20)^{b}\end{array}$ & 1.15 \\
\hline 4 & Imidacloprid $17.8 \% \mathrm{SL}$ & 22.66 & 13.33 & 7.66 & $\begin{array}{c}44.72 \\
(41.96)^{c}\end{array}$ & $\begin{array}{c}67.48 \\
(55.23)^{c}\end{array}$ & $\begin{array}{l}81.30 \\
(64.39)^{c}\end{array}$ & 0.94 \\
\hline 5 & Chlorantraniliprole $0.4 \% \mathrm{G}$ & 27.63 & 25.33 & 23.93 & $\begin{array}{c}32.60 \\
(34.81)^{\mathrm{ab}}\end{array}$ & $\begin{array}{c}38.21 \\
(38.18)^{b}\end{array}$ & $\begin{array}{c}41.63 \\
(40.18)^{\mathrm{ab}}\end{array}$ & 1.23 \\
\hline 6 & Hexaconazole $5 \%$ SC & 0.00 & 0.00 & 0.00 & $\begin{array}{c}100 \\
(90)^{d}\end{array}$ & $\begin{array}{c}100 \\
(90)^{d}\end{array}$ & $\begin{array}{c}100 \\
(90)^{d}\end{array}$ & 0.00 \\
\hline 7 & Propiconazole $25 \%$ EC & 0.00 & 0.00 & 0.00 & $\begin{array}{c}100 \\
(90)^{d}\end{array}$ & $\begin{array}{c}100 \\
(90)^{d}\end{array}$ & $\begin{array}{l}100 \\
(90)^{d}\end{array}$ & 0.00 \\
\hline 8 & Control & 41.00 & 41.00 & 41.00 & - & - & - & 2.01 \\
\hline & Factors & \multicolumn{4}{|c|}{ S.Em. + } & \multicolumn{3}{|c|}{ C.D. at $1 \%$} \\
\hline & Insecticides (I) & \multicolumn{4}{|c|}{0.32} & \multicolumn{3}{|c|}{1.24} \\
\hline & Concentration $(\mathrm{C})$ & \multicolumn{4}{|c|}{0.21} & \multicolumn{3}{|c|}{0.81} \\
\hline & $\mathbf{I} \times \mathbf{C}$ & \multicolumn{3}{|c|}{0.56} & & \multicolumn{3}{|c|}{2.15} \\
\hline & $\mathbf{C V}$ & \multicolumn{7}{|c|}{1.57} \\
\hline
\end{tabular}

$* \mathrm{DAI}=$ Days after inoculation, $* * \mathrm{RD}=$ Recommended dose, Figures in parentheses are arc sine transformed values, means followed by the same alphabets in columns do not differ significantly $(\mathrm{p}=$ $0.01)$ by DMRT 
Fig 1. Effect of pesticides on colony diameter, growth inhibition and spore yield of $M$. anisopliaeon 10th days after inoculation

\begin{tabular}{|lll}
\hline$\square$ Fipronil $5 \%$ SC & $\square$ Chlorpyriphos $20 \%$ EC & $\square$ Imidacloprid $40 \%+$ Fipronil $40 \%$ WG \\
$\square$ Imidacloprid $17.8 \%$ SL & $\square$ Chlorantraniliprole $0.4 \%$ G & $\square$ Hexaconazole $5 \%$ SC \\
$\square$ Propiconazole $25 \%$ EC & & \\
\hline
\end{tabular}

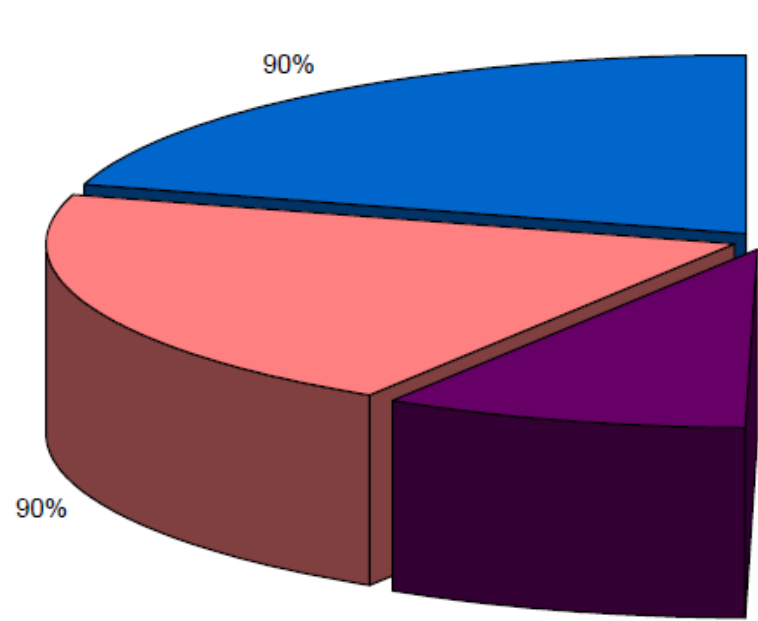

$37.72 \%$

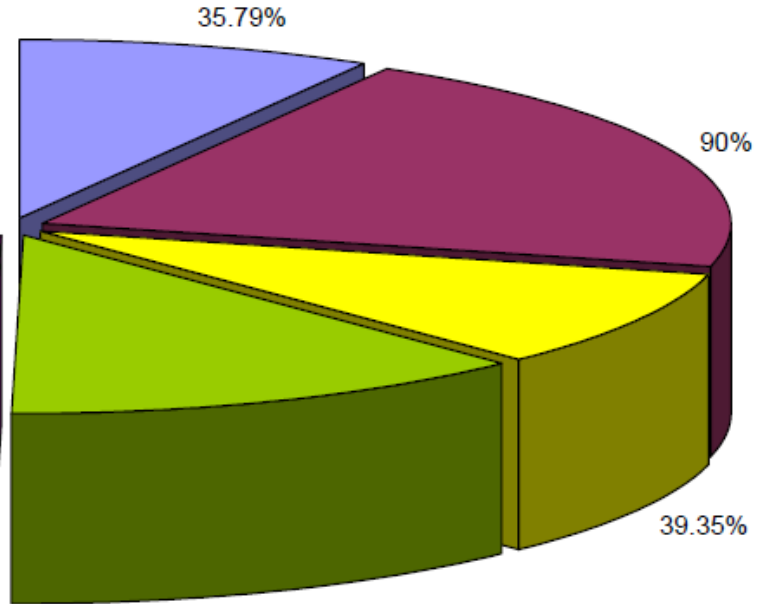

$53.86 \%$

Plate.1 Compatibility of Metarhizium anisopliae with pesticides

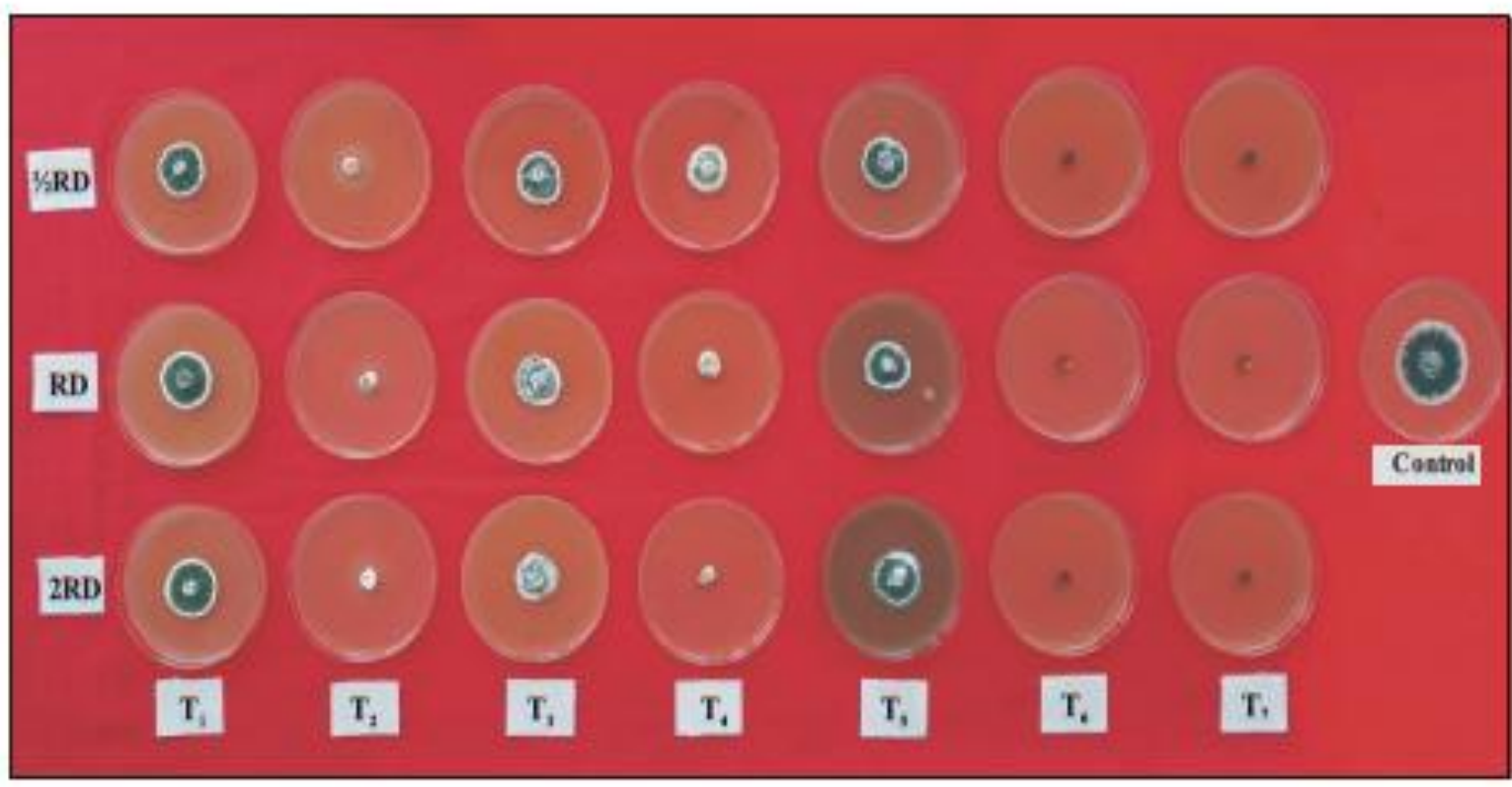

The findings of present study is in line with that at lowest concentration of the findings of Joshi et al., (2018) reported chlorantraniliprole $0.4 \% \mathrm{G}$ produced 76 per 
cent of spore germination. Faraji et al., (2016) reported that imidacloprid at lower concentration significantly allowed the germination, mycelial growth and sporulation of M. anisopliae. Abdul et al., (1987), Asiet al., (2010) and Akbar et al., (2012) their findings reveals that chlorpyriphos was most toxic organophosphate insecticide which inhibited Metarhizium growth completely (Plate.1). The findings of Samson et al., (2005), Joshi et al., (2018) results are in line with outcomes of present studies, they reported that propiconazole and hexaconazole found to be highly incompatible with $M$. anisopliae.

In conclusion, fipronil $5 \% \quad \mathrm{SC}$ and Chlorantraniliprole $0.4 \% \quad \mathrm{G}$ found most compatible with $M$. anisopliae. Chlopyriphos $20 \%$ EC, Hexaconazole 5\% SC and Propiconazole $25 \%$ EC found highly incompatible.

\section{Acknowledgments}

Authors are thankful to the Department of Plant Pathology, College of Agriculture, Dharwad for providing facilities required to conduct this experiments.

\section{References}

Abdul, K. A. M., Joann, P. P. and Fred, R. S. N., 1987.Compatability of Metarhizium anisopliaevar. Anisopliae with chemical pesticides. Mycopathologia. 99: 99-105.

Akbar, S., Shoaib, F., Asifa, H., Hafiza, T. G., Muhammad, A., Muhammad, N. M., Muhammad.N. and Muhammad, B. K., 2012. Compatibility of Metarhizium anisopliae with different insecticides and fungicides. African. J. Microbiol. Res.6(17): 3956-3962.

Anderson, T. E. and Roberts, D. W., 1983. Compatibility of Beauveria bassianas train with formulations used in
Colorado Potato beetle (Coleoptera: Chrysomelidae) control. J. Econ. Entomol. 76:1437-1441.

Asi, M. R., Bashir, M. H., Afzal, M., Ashfaq, M. andSahi, S. T., 2010.Compatibility of entomopathogenic fungi, Metarhizium anisopliae and Paecilomyces fumosoroseus with selective insecticides. Pak. J. Bot. 42(6): 4207-4214.

Carruthers, R. I. and Hural, K., 1990. Fungi as naturally occurring entomopathogens. Symp. On Molecular and Cellular Biology. 112:115-138.

Faraji, S., Derakhshan, A. S. and Mehrvar, A., 2016. Compatibility of entomopathogenic fungi Beauveria bassiana and Metarhizium anisopliae with some pesticides. J. Entomol. Society. Iran. 36(2): 137-146.

Joshi, M., Gaur, N. and Pandey, R., 2018. Compatibility of entomopathogenic fungi Beauveria bassiana and Metarhizium anisopliae with selective pesticides. J. Entomol. Zool. Studies.6(4): 867-872.

Li, D. P. and Holdom, D. G., 1994. Effects of pesticides on growth and sporulation of Metarhizium anisopliae (Deuteromycotina: Hyphomycets). $J$. Invertebr. Pathol. 63: 209-211.

Moorhouse, E. R., Gillsepie, A. T., Sellers, E. K. and Charnley, A. K., 1992. Influence of fungicides and insecticides on the entomogenous fungus, Metarhizium anisopliae a pathogen of the vine weevil, Otiorhynchus sulcatus. Biocont. Sci. Tech. 82: 404-407.

Nene, Y. L. and Thapliyal, P. N., 1997. Fungicides in plant disease control. Oxford and IBH Publishing Co. Pvt. Ltd., New Delhi. Pp. 531.

Samson, P. R., Milner, R.J., Sander, E.D. and Bullard, G. K., 2005. Effect of fungicides and insecticides applied during planting of sugarcane on 
viability of Metarhizium anisopliae and its efficacy against white grubs. Biocont. 50: 151-163.
Vincent, J. M., 1947. Distortion of fungal hyphae in the presence of certain inhibitor. Nature. 159:800.

\section{How to cite this article:}

Lavanya, D. S. and Poornima Matti. 2020. Compatibility of Entomopathogenic Fungi, Metarhizium anisopliae with Pesticides. Int.J.Curr.Microbiol.App.Sci. 9(02): 714-721. doi: https://doi.org/10.20546/ijcmas.2020.902.087 